\title{
Study on the Spectral Interference of Thorium on Critical Elements and Rare Earths by CCD-based ICP-AES
}

\author{
Arijit Sengupta*, S.K.Thulasidas, and V. Natarajan \\ Radiochemistry Division, Bhabha Atomic Research Centre \\ Trombay, Mumbai, India
}

\begin{abstract}
Thorium is one of the key elements in the three-stage nuclear energy program of India. Due to the line-rich emission spectra of thorium, it is likely to interfere in the determination of trace metallic impurities by ICP-AES in a Th matrix. In this work, a systematic study was carried out to understand the spectral interference of Th on rare earths and all the critical elements (Ag, B, Ce, Eu, Gd, Dy, Sm, La, Nd, Er, Y, Ce, Lu, Pr, $\mathrm{Yb}$ ) which have very stringent specification limits for the chemical quality control of Th-based fuels and nuclear materials. Due to the advancement of the capacitatively coupled detector (CCD) system, additional analytical lines of the analytes are available, which enhances the possibility of choosing relatively interferencefree alternative analytical lines.

The present study includes the development of an ICP-AES-based analytical method for the determination of Th, which is essential for calculating correction factors of interfered lines. The calibration curves established for four different analytical lines of Th $(274.716$ $\mathrm{nm}, 283.231 \mathrm{~nm}, 283.730 \mathrm{~nm}$,
\end{abstract}

and $401.913 \mathrm{~nm}$ ) revealed the best analytical performance for Th at the $401.913 \mathrm{~nm}$ line. It was also observed that all four analytical lines can be used for the determination of Th up to 1000 $\mu \mathrm{g} / \mathrm{mL}$ within a RSD of $2 \%$. The spectral interference of Th was studied along with the correction factors and the tolerance level of Th on several recommended analytical lines of all the rare earths and critical elements mentioned above. The analytical performance, including the detection limits and sensitivity of all these lines, were studied in the presence of a Th matrix. For the critical elements Ag at $338.289 \mathrm{~nm}, \mathrm{~B}$ at $208.959 \mathrm{~nm}, \mathrm{Cd}$ at 214.438 $\mathrm{nm}, \mathrm{Sm}$ at $442.434 \mathrm{~nm}, \mathrm{Gd}$ at $335.047 \mathrm{~nm}$, and Dy at 364.540 $\mathrm{nm}$, the analytical lines of the corresponding elements were found to have the least spectral interference from Th. The analytical lines of $\mathrm{Nd}$ at $406.109 \mathrm{~nm}$, Er at $326.478 \mathrm{~nm}, Y$ at $371.030 \mathrm{~nm}$, Pr at $422.535 \mathrm{~nm}, \mathrm{La}$ at 379.478 $\mathrm{nm}$, Ce at $418.660 \mathrm{~nm}$, Lu at $261.542 \mathrm{~nm}, \mathrm{Yb}$ at $328.937 \mathrm{~nm}$, and $\mathrm{La}$ at $379.478 \mathrm{~nm}$ are suitable for the determination of these analytes in the presence of a Th matrix.

\section{INTRODUCTION}

Trace metallic impurity analysis is one of the prime tasks of chemical quality control of nuclear fuels and associated materials (1-6). Due to the high neutron absorption cross-section of the rare earth elements of Ag, B, and Cd, they have

\footnotetext{
* Corresponding autbor.

E-mail: arijita@barc.gov.in
}

stringent specification limits. The presence of these elements beyond the specification limits can also change the metallurgical properties of the fuel materials. To achieve the desired burn-up, the successful life span of the fuel in the reactor, and the successful running of the reactor, it is required to have stringent physical and chemical quality control and quality assurance measures of the nuclear fuels and associated materials. The major problem in the determination of trace analytes in nuclear materials by inductively coupled plasma atomic emission spectrometry (ICP-AES) is the spectral interference of matrix elements such as $\mathrm{U}, \mathrm{Pu}, \mathrm{Zr}$, Th, etc., originating from their line-rich emission spectra. Chemical (7-12) or physical (13-18) separation of the major matrix followed by the determination of trace metallic impurities in the raffinate is a well accepted protocol in the nuclear industry. Separation involves handling of the materials, which increases the chances of contamination, loss of analytes, etc. The charge-coupled detector (CCD) has the flexibility of choosing additional analytical lines for the selected analyte, which can have less interference from the major matrix (19-22).

Concerns about the limits of worldwide uranium resources motivated the initial interest in the thorium fuel cycle (23). It was envisioned that as uranium reserves get depleted, thorium would supplement uranium as a fertile material. However, for most countries uranium was still relatively abundant and research in thorium fuel cycles waned. A notable exception was India's three-stage nuclear power program (24). In the twenty-first century, thorium's potential for improving proliferation resistance and waste characteristics led to renewed interest in the thorium fuel cycle (25-27). Thorium is estimated to be about three to four times more abundant than uranium in the Earth's crust (28), although present knowledge of reserves is limited. Current demand for thorium has been satisfied as a by-product of rare earth extraction from monazite sands. Thorium-based fuels exhibit several attractive prop- 
erties relative to uranium-based fuels. The thermal neutron absorption cross-section $\left(\sigma_{\mathrm{a}}\right)$ and resonance integral (average of neutron cross-sections over intermediate neutron energies) for ${ }^{232} \mathrm{Th}$ are about three times and one third of the respective values for ${ }^{238} \mathrm{U}$; consequently, fertile conversion of thorium is more efficient in a thermal reactor. Also, although the thermal neutron fission cross-section $\left(\sigma_{f}\right)$ of the resulting ${ }^{233} \mathrm{U}$ is comparable to ${ }^{235} \mathrm{U}$ and ${ }^{239} \mathrm{Pu}$, it has a much lower capture cross-section $\left(\sigma_{y}\right)$ than the latter two fissile isotopes, providing fewer non-fissile neutron absorptions and improved neutron economy. Finally, the ratio of neutrons released per neutron absorbed $(\eta)$ in ${ }^{233} \mathrm{U}$ is greater than two over a wide range of energies, including the thermal spectrum. As a result, thorium-based fuels can be the basis for a thermal breeder reactor. Thorium-based fuels also display favorable physical and chemical properties, which improve reactor and repository performance.

In view of the above, in the present work an attempt was made to understand the spectral interference of thorium on rare earths and critical elements. The study includes identification of relatively interference-free analytical lines, correction factors, and Th tolerance levels along with the analytical performance of these lines. An ICPAES-based method was also developed to determine Th, which is important in order to evaluate the correction factors due to thorium contribution.

\section{EXPERIMENTAL}

\section{Instrumentation}

A computer-controlled, high resolution, simultaneous atomic emission spectrometer (Spectro Arcos, Germany) with ICP and DC arc as excitation sources and a charge coupled device (CCD) detector was utilized for carrying out all analyti- cal experiments. The instrumental specifications and experimental parameters are summarized in Table I. The detector system, consisting of linear arrays of the CCD detector (3648 pixels/array), thermally stabilized together with an optical system, provides the ability to choose the alternate analytical lines.

\section{Standard Solutions and Reagents}

Standard solutions for rare earth and other critical elements were prepared from CertiPUR ${ }^{\circledR}$ ICP multi-standard solutions (E-Merck, Darmstadt, Germany) by proper dilution with $0.5 \mathrm{M} \mathrm{HNO}_{3}$. Suprapur ${ }^{\circledR} \mathrm{HNO}_{3}$ (E-Merck, Darmstadt, Germany) and quartz doubly distilled water were used to prepare $0.5 \mathrm{M} \mathrm{HNO}_{3}$. Multi-point standard-

\section{TABLE I}

Specifications and Operating Conditions of ICP-AES

\begin{tabular}{|c|c|}
\hline \multicolumn{2}{|c|}{$\begin{array}{c}\text { TABLE I } \\
\text { Specifications and Operating Conditions of ICP-AES }\end{array}$} \\
\hline & Instrumental Specifications \\
\hline Optical design & Paschen-Runge mounting, Circular design \\
\hline Focal length & $750 \mathrm{~mm}$ \\
\hline Grating & Holographic \\
\hline Groove density & 1800 grooves/mm (1), 3600 grooves/mm (2) \\
\hline Wavelength range & $130-800 \mathrm{~nm}$ \\
\hline Entrance slit width & 15 microns \\
\hline \multirow[t]{2}{*}{ Resolution (FWHM) } & $0.01 \mathrm{~nm}$ from $130-450 \mathrm{~nm}$ \\
\hline & $0.02 \mathrm{~nm}$ from $450-800 \mathrm{~nm}$ \\
\hline Thermal regulation & Controlled to $30 \pm 1{ }^{\circ} \mathrm{C}$ \\
\hline Frequency & $27.12 \mathrm{MHz}$ \\
\hline Pump & Dual channel peristaltic pump \\
\hline Detector & Linear arrays of CCD (3648 pixels/array) \\
\hline Nebulizer & $\begin{array}{l}\text { Concentric nebulizer with cyclonic spray } \\
\text { chamber }\end{array}$ \\
\hline \multirow[t]{2}{*}{ ICP torch } & Demountable, radial viewing \\
\hline & Operating Condition \\
\hline Coolant flow & $6 \mathrm{~L} / \mathrm{min}$ \\
\hline Auxiliary flow & $0.6 \mathrm{~L} / \mathrm{min}$ \\
\hline Total time of measurement & $28 \mathrm{~s}$ \\
\hline Pump speed & $30 \mathrm{Rpm}$ \\
\hline RF power output & $0.8-1.5 \mathrm{~kW}$ \\
\hline Input power & $230 \mathrm{~V} \mathrm{AC}$ \\
\hline
\end{tabular}

ization was carried out using $0.5 \mathrm{M}$ $\mathrm{HNO}_{3}$ as the lower standard and $0.05-1000 \mu \mathrm{g} / \mathrm{mL}$ of the corresponding elemental standard as the higher standards for each line after proper peak search.

\section{Methods}

A series of Th solutions having a concentration range between $0.05 \mu \mathrm{g} / \mathrm{mL}$ to $1000 \mu \mathrm{g} / \mathrm{mL}$ were fed to the plasma. The contribution of Th in different analytical channels of the critical elements and the rare earths were monitored to understand the spectral interference of Th.

The analytical performance, i.e., detection limits, sensitivity, linear dynamic range, establishing the calibration curves of all the analytical lines of Th, critical elements and 
rare earths, was studied. The sensitivity and detection limits of the above-mentioned analytical lines were evaluated using the slopes of the calibration curves and the concentration equivalent to the intensity equal to the average of the blank value + three times the standard deviation of the above measurements, i.e., $x+3 \sigma$.

\section{RESULTS AND DISCUSSION}

\section{Development of ICP-AES-based Methodology for the Determina- tion of $\mathbf{T h}$}

Due to the line-rich emission characteristic of thorium, the study of the spectral interference of Th on rare earths and critical elements is necessary during trace metal characterization of the Th-based fuel and nuclear materials which is an integral part of chemical quality control. To study the spectral interference of thorium, it is required to determine Th simultaneously since the interference is highly dependent on the concentration of the interfering elements. Exploring the superior analytical performance of the CCD-based detector system, an analytical method was developed for the determination of Th by ICPAES. The study includes identification of the suitable analytical lines. The four analytical lines of Th identified for the present study are: $274.160 \mathrm{~nm}, 283.736 \mathrm{~nm}, 283.231$ $\mathrm{nm}$, and $401.913 \mathrm{~nm}$. The calibration curves of those lines (Figure 1) and their analytical performance including sensitivity, detection limits, etc., were studied. The sensitivity and detection limits of the $283.231 \mathrm{~nm}$ and $283.736 \mathrm{~nm}$ analytical lines were found to be similar (sensitivity $\sim 35,000$ counts $/ \mu \mathrm{g} / \mathrm{mL}$ and detection limit $\sim 0.001 \mu \mathrm{g} / \mathrm{mL}$ ). The Th $401.913 \mathrm{~nm}$ line was found to have higher sensitivity and better detection limits ( 64,000 counts/ $\mu \mathrm{g} / \mathrm{mL}$ and $0.0009 \mu \mathrm{g} / \mathrm{mL}$, respectively) among the four lines chosen in the present case. Synthetic samples having different Th concentrations $(0.05 \mu \mathrm{g} / \mathrm{mL}$ to $1000 \mu \mathrm{g} / \mathrm{mL})$ were fed to the plasma, and these four analytical lines of Th were monitored, which revealed that

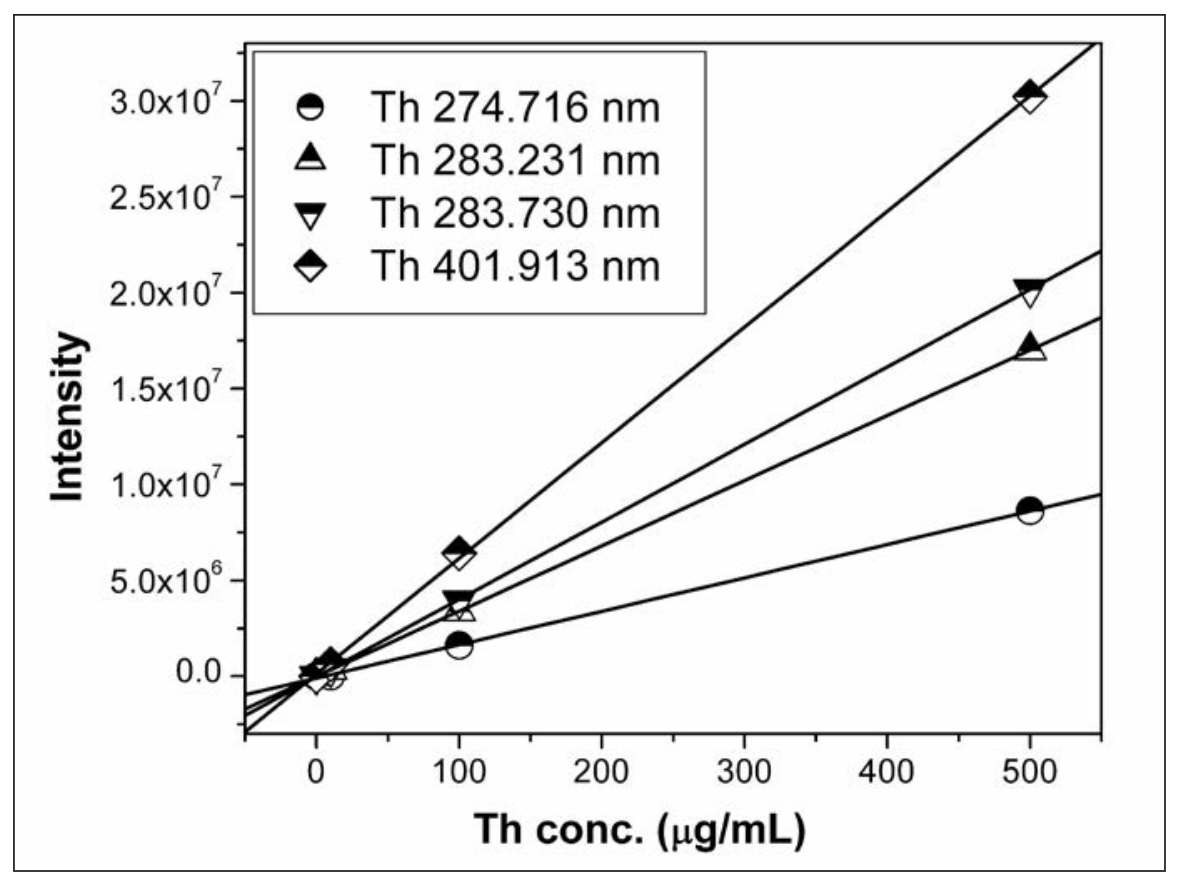

Fig. 1. Calibration curves for different analytical lines of thorium.

\section{Atomic Apectroscopy 1 Vol. 35(5), Sept./Oct. 2014}

though all of these analytical lines can be used for the determination Th by ICP-AES, the Th $401.913 \mathrm{~nm}$ line is the best. The analytical results of the Th determination in synthetic samples are summarized in Table II. The MultiComponent Spectral Fitting (MSF) approach involving solutions of complicated mathematical equations were adopted by many researchers to address the solution of spectral interference problems in ICP-AES (29-32). But we believe our methodology in the simultaneous determination of Th along with the analytes is simple and not only useful in evaluating the correction factors due to the Th spectral interference, but also the fissile content in nuclear materials.

\section{Spectral Interference of Th on Critical Elements}

Since B, Cd, Ag, Eu, Gd, Dy, and $\mathrm{Sm}$ have stringent specification limits due to their large neutron absorption cross-section, a careful control of these constituents at each step of fuel fabrication is essential. Therefore it is required to study the spectral interference of Th on the analytical lines of those elements to avoid the overestimation of these elements, which is detrimental in qualifying the nuclear materials for the reactor. Table III summarizes the outcome of the spectral interference study of Th on the critical elements, while Table IV summarizes the analytical performance of those lines in the presence of the Th matrix.

\section{Silver, Boron, and Cadmium \\ Silver (Ag)}

Four different analytical lines of $\mathrm{Ag}$ (328.068 nm, $338.289 \mathrm{~nm}$, $224.641 \mathrm{~nm}$, and $243.779 \mathrm{~nm}$ ) were chosen for the present purpose. The Ag 224.641 nm line was found to be highly interfered by Th, and the tolerance level of Th is below $0.05 \mu \mathrm{g} / \mathrm{mL}$, whereas at the $50 \mu \mathrm{g} / \mathrm{mL}$ tolerance level of $\mathrm{Th}$, the 
TABLE II

Determination of Th by ICP-AES Using Different Analytical Lines

\begin{tabular}{|c|c|c|c|c|}
\hline $\begin{array}{c}\text { Th } \\
(\mu \mathrm{g} / \mathrm{mL})\end{array}$ & $\begin{array}{c}\text { Th } \\
401.913 \mathrm{~nm} \\
(\mu \mathrm{g} / \mathrm{mL})\end{array}$ & $\begin{array}{c}\text { Th } \\
283.730 \mathrm{~nm} \\
(\mu \mathrm{g} / \mathrm{mL})\end{array}$ & $\begin{array}{c}\text { Th } \\
274.716 \mathrm{~nm} \\
(\mu \mathrm{g} / \mathrm{mL})\end{array}$ & $\begin{array}{c}\text { Th } \\
283.231 \mathrm{~nm}\end{array}$ \\
\hline 0.05 & 0.06 & 0.04 & 0.04 & 0.04 \\
\hline 1 & 0.86 & 0.98 & 0.94 & 0.98 \\
\hline 0.5 & 0.49 & 0.47 & 0.47 & 0.50 \\
\hline 5 & 4. 8 & 4.7 & 4.8 & 4.9 \\
\hline 10 & 9.8 & 9.9 & 9.7 & 9.9 \\
\hline 50 & 51.8 & 49.3 & 50.5 & 50.2 \\
\hline 100 & 98.5 & 102.1 & 100.3 & 101.6 \\
\hline 500 & 497.2 & 499.1 & 497.9 & 502.1 \\
\hline 1000 & 1000.9 & 998.6 & 994.9 & 1001.3 \\
\hline $\begin{array}{c}\text { D.L. } \\
(\mu \mathrm{g} / \mathrm{mL})\end{array}$ & 0.0009 & 0.001 & 0.0028 & 0.0015 \\
\hline $\begin{array}{c}\text { Sensitivity } \\
(\text { counts } / \mu \mathrm{g} / \mathrm{mL})\end{array}$ & 64055 & 39423 & 16149 & 33832 \\
\hline
\end{tabular}

TABLE III

Spectral Interference of Th on Critical Elements

\begin{tabular}{|c|c|c|c|c|c|c|c|c|c|}
\hline Metal & $\begin{array}{l}\text { Analytical } \\
\text { Lines } \\
(\mathrm{nm})\end{array}$ & $\begin{array}{l}\text { Contribution } \\
\text { From } \\
1000 \mu \mathrm{g} / \mathrm{mL} \\
\text { of } \mathrm{Th}(\mu \mathrm{g} / \mathrm{mL})\end{array}$ & $\begin{array}{l}\text { Correction } \\
\text { Factor } \\
(\mu \mathrm{g} / \mathrm{mL} \text { per } \\
\mu \mathrm{g} / \mathrm{mL} \text { of } \mathrm{Th})\end{array}$ & $\begin{array}{l}\text { Tolerance } \\
\text { Level } \\
\text { of Th } \\
(\mu \mathrm{g} / \mathrm{mL})\end{array}$ & Metal & $\begin{array}{l}\text { Analytical } \\
\text { Lines } \\
\text { (nm) }\end{array}$ & $\begin{array}{l}\text { Contribution } \\
\text { From } \\
1000 \mu \mathrm{g} / \mathrm{mL} \\
\text { of } \mathrm{Th}(\mu \mathrm{g} / \mathrm{mL})\end{array}$ & $\begin{array}{l}\text { Correction } \\
\text { Factor } \\
(\mu \mathrm{g} / \mathrm{mL} \text { per } \\
\mu \mathrm{g} / \mathrm{mL} \text { of } \mathrm{Th})\end{array}$ & $\begin{array}{l}\text { Tolerance } \\
\text { Level } \\
\text { of } \mathrm{Th} \\
(\mu \mathrm{g} / \mathrm{mL})\end{array}$ \\
\hline \multirow[t]{4}{*}{$\mathrm{Ag}$} & 328.068 & 3.37 & $3.37 \mathrm{E}-03$ & 10 & \multirow[t]{4}{*}{ Dy } & 353.17 & 1.386 & $1.39 \mathrm{E}-03$ & 50 \\
\hline & 338.289 & 0.85 & $8.50 \mathrm{E}-04$ & 50 & & 394.468 & 0.739 & 7.39E-04 & 100 \\
\hline & 224.641 & 7.93 & $7.93 \mathrm{E}-03$ & $<0.05$ & & 340.78 & 1.638 & $1.64 \mathrm{E}-03$ & 50 \\
\hline & 243.779 & 5.25 & $5.25 \mathrm{E}-03$ & 0.1 & & 353.602 & 1.153 & $1.15 \mathrm{E}-03$ & 50 \\
\hline \multirow[t]{5}{*}{ B } & 249.773 & 0.47 & $4.70 \mathrm{E}-04$ & 100 & \multirow{5}{*}{$\mathrm{Eu}$} & 364.54 & 0.572 & $5.72 \mathrm{E}-04$ & 100 \\
\hline & 249.677 & 0.51 & $5.10 \mathrm{E}-04$ & 50 & & 420.505 & 0.126 & $1.26 \mathrm{E}-04$ & 500 \\
\hline & 182.641 & 0.19 & $1.90 \mathrm{E}-04$ & 100 & & 381.967 & BDL & - & 1000 \\
\hline & 208.959 & 0.16 & $1.60 \mathrm{E}-04$ & 100 & & 393.048 & 0.264 & $2.64 \mathrm{E}-04$ & 500 \\
\hline & 136.246 & 3.94 & $3.94 \mathrm{E}-03$ & 2 & & 390.71 & 0.228 & $2.28 \mathrm{E}-04$ & 500 \\
\hline \multirow[t]{4}{*}{$\mathrm{Cd}$} & 214.438 & BDL & - & 1000 & \multirow[t]{4}{*}{ Gd } & 342.247 & 1.159 & $1.16 \mathrm{E}-03$ & 50 \\
\hline & 226.502 & 0.09 & $9.00 \mathrm{E}-05$ & 500 & & 335.047 & 0.508 & $5.08 \mathrm{E}-04$ & 100 \\
\hline & 228.802 & 0.26 & $2.60 \mathrm{E}-04$ & 100 & & 336.223 & 5.226 & $5.23 \mathrm{E}-03$ & 5 \\
\hline & 361.051 & 196 & $1.96 \mathrm{E}-01$ & 0.05 & & & 200 & & 0.5 \\
\hline \multirow[t]{4}{*}{$\mathrm{Sm}$} & 359.26 & 1.99 & $1.99 \mathrm{E}-03$ & 10 & & & & & \\
\hline & 442.434 & 0.35 & $3.50 \mathrm{E}-04$ & 100 & & & & & \\
\hline & 428.079 & 10 & $1.00 \mathrm{E}-02$ & 5 & & & & & \\
\hline & 360.428 & 2.01 & $2.01 \mathrm{E}-03$ & 10 & & & & & \\
\hline
\end{tabular}


Ag 338.289 $\mathrm{nm}$ line is least interfered among the group. On the basis of the analytical performance, the Ag $328.068 \mathrm{~nm}$ and $338.289 \mathrm{~nm}$ lines were found to be better. Considering both facts, the $338.289 \mathrm{~nm}$ line of $\mathrm{Ag}$ is the best analytical line in the presence of $\mathrm{Th}$.

\section{Boron (B)}

Five different analytical lines of B (249.773 nm, $249.667 \mathrm{~nm}, 182.641$ $\mathrm{nm}, 208.959 \mathrm{~nm}$, and $136.246 \mathrm{~nm}$ ) were considered for the present purpose. The B $136.246 \mathrm{~nm}$ line showed maximum spectral interference and minimum tolerance level of Th $(2 \mu \mathrm{g} / \mathrm{mL})$, while the 249.773 $\mathrm{nm}, 182.641 \mathrm{~nm}$, and $208.959 \mathrm{~nm}$ lines showed maximum tolerance

TABLE IV

Analytical Performance of Specified Analytical Lines of Critical Elements

\begin{tabular}{|c|c|c|c|}
\hline Elements & $\begin{array}{l}\text { Analytical Lines } \\
\text { (nm) }\end{array}$ & $\begin{array}{c}\text { D.L. } \\
(\mu \mathrm{g} / \mathrm{mL})\end{array}$ & $\begin{array}{c}\text { Sensitivity } \\
(\text { counts } / \mu \mathrm{g} / \mathrm{mL})\end{array}$ \\
\hline \multirow[t]{4}{*}{ Ag } & 224.641 & 0.18 & 624 \\
\hline & 243.779 & 0.029 & 2286 \\
\hline & 328.068 & 0.0006 & 145353 \\
\hline & 338.289 & 0.0007 & 67516 \\
\hline \multirow[t]{5}{*}{ B } & 136.246 & 0.109 & 333 \\
\hline & 182.641 & 0.0025 & 12052 \\
\hline & 208.959 & 0.0093 & 27298 \\
\hline & 249.677 & 0.0098 & 10496 \\
\hline & 249.773 & 0.0041 & 14490 \\
\hline \multirow[t]{4}{*}{$\mathrm{Cd}$} & 214.438 & 0.0018 & 115513 \\
\hline & 226.502 & 0.0014 & 127721 \\
\hline & 228.802 & 0.0031 & 41729 \\
\hline & 361.051 & 0.017 & 2579 \\
\hline \multirow[t]{5}{*}{ Dy } & 340.78 & 0.004 & 38728 \\
\hline & 353.17 & 0.0005 & 191940 \\
\hline & 353.602 & 0.002 & 52369 \\
\hline & 364.54 & 0.0017 & 65767 \\
\hline & 394.468 & 0.001 & 51335 \\
\hline \multirow[t]{4}{*}{$\mathrm{Eu}$} & 381.967 & 0.00003 & 444758 \\
\hline & 390.71 & 0.0002 & 662917 \\
\hline & 393.048 & 0.0014 & 226439 \\
\hline & 420.505 & 0.0007 & 321797 \\
\hline \multirow[t]{4}{*}{ Gd } & 335.047 & 0.0011 & 86618 \\
\hline & 335.862 & 0.012 & 53425 \\
\hline & 336.223 & 0.002 & 69432 \\
\hline & 342.247 & 0.001 & 65218 \\
\hline \multirow[t]{4}{*}{$\mathrm{Sm}$} & 359.26 & 0.001 & 39906 \\
\hline & 360.428 & 0.001 & 15091 \\
\hline & 428.079 & 0.0005 & 22564 \\
\hline & 442.434 & 0.0049 & 36387 \\
\hline
\end{tabular}




\section{Samarium (Sm)}

For $\mathrm{Sm}$, the best line at 428.079 nm showed maximum spectral interference from Th, while the least interfered line of $442.434 \mathrm{~nm}$ showed poor analytical performance. Out of four chosen lines of Sm $(359.260 \mathrm{~nm}, 442.434 \mathrm{~nm}$, $428.079 \mathrm{~nm}$, and $360.428 \mathrm{~nm}$ ), the $359.260 \mathrm{~nm}$ line is the best option for $\mathrm{Sm}$ determination in the presence of the Th matrix. Appropriate correction factors as shown in Table III should be applied during estimation.

\section{Dysprosium (Dy)}

The tolerance level of Th for Dy at the $353.170 \mathrm{~nm}, 394.468 \mathrm{~nm}$, $340.780 \mathrm{~nm}, 353.602 \mathrm{~nm}$, and $364.540 \mathrm{~nm}$ analytical lines were found to be $50 \mu \mathrm{g} / \mathrm{mL}, 100 \mu \mathrm{g} / \mathrm{mL}$, $50 \mu \mathrm{g} / \mathrm{mL}, 50 \mu \mathrm{g} / \mathrm{mL}$, and 100 $\mu \mathrm{g} / \mathrm{mL}$, respectively. Higher sensitivity and better detection limits were observed for the $353.170 \mathrm{~nm}$ line of Dy (sensitivity $=191940$ counts $/ \mu \mathrm{g} / \mathrm{mL}$ and D.L. $=0.0005$ $\mu \mathrm{g} / \mathrm{mL}$ ). It can be concluded that the $394.468 \mathrm{~nm}$ Dy line is a better choice for Dy determination in a Th matrix after applying the suitable correction factors specified in Table III.

\section{Spectral Interference of Th on Other Rare Earth Elements}

All other rare earth elements not only dilute the fissile content of the fuel and associated nuclear materials, but are also important from the neutron economy point of view. Further, most of the rare earth elements have line-rich emission spectra; therefore, it was also of interest to study the spectral interference of Th on their determination. The spectral interference of Th on different analytical lines of rare earths is presented in Table $\mathrm{V}$, whereas Table VI presents the analytical performance of these lines in the presence of Th matrix.
TABLE V

Spectral Interference of Th on Rare Earth Elements

\begin{tabular}{|c|c|c|c|c|}
\hline Metal & $\begin{array}{l}\text { Analytical } \\
\text { Lines } \\
\text { (nm) }\end{array}$ & $\begin{array}{c}\text { Contribution From } \\
1000 \mu \mathrm{g} / \mathrm{mL} \text { of } \mathrm{Th} \\
(\mu \mathrm{g} / \mathrm{mL})\end{array}$ & $\begin{array}{l}\text { Correction } \\
\text { Factor }\end{array}$ & $\begin{array}{l}\text { Tolerance } \\
\text { Level of Th } \\
(\mu \mathrm{g} / \mathrm{mL})\end{array}$ \\
\hline \multirow[t]{4}{*}{$\mathrm{Nd}$} & 401.225 & 0.65 & $6.50 \mathrm{E}-04$ & 100 \\
\hline & 430.358 & 0.26 & $2.60 \mathrm{E}-04$ & 100 \\
\hline & 406.109 & 0.19 & $1.90 \mathrm{E}-04$ & 100 \\
\hline & 417.731 & 2.96 & $2.96 \mathrm{E}-03$ & 5 \\
\hline \multirow[t]{4}{*}{ Er } & 337.271 & 1.88 & $1.88 \mathrm{E}-03$ & 10 \\
\hline & 349.91 & 2.23 & $2.23 \mathrm{E}-03$ & 10 \\
\hline & 326.478 & 0.49 & $4.90 \mathrm{E}-04$ & 100 \\
\hline & 323.058 & 0.42 & $4.20 \mathrm{E}-04$ & 100 \\
\hline \multirow[t]{5}{*}{$\mathrm{Ce}$} & 418.66 & 0.29 & $2.90 \mathrm{E}-04$ & 50 \\
\hline & 448.691 & Large spectral interference & Rejected & $<0.05$ \\
\hline & 413.765 & 4.08 & $4.08 \mathrm{E}-03$ & 5 \\
\hline & 413.38 & 4.39 & $4.39 \mathrm{E}-03$ & 5 \\
\hline & 393.373 & Large spectral interference & Rejected & $<0.05$ \\
\hline \multirow[t]{9}{*}{ Y } & 371.03 & 0.096 & $9.60 \mathrm{E}-05$ & 100 \\
\hline & 324.228 & 1.929 & $1.93 \mathrm{E}-03$ & 10 \\
\hline & 360.073 & 0.949 & $9.49 \mathrm{E}-04$ & 10 \\
\hline & 224.306 & Large spectral interference & Rejected & $<0.05$ \\
\hline & 377.433 & 1.148 & $1.15 \mathrm{E}-03$ & 10 \\
\hline & 320.332 & 1.003 & $1.00 \mathrm{E}-03$ & 10 \\
\hline & 349.609 & 1.773 & $1.77 \mathrm{E}-03$ & 10 \\
\hline & 362.871 & 0.345 & $3.45 \mathrm{E}-04$ & 10 \\
\hline & 442.259 & 1.424 & $1.42 \mathrm{E}-03$ & 5 \\
\hline \multirow[t]{4}{*}{$\operatorname{Pr}$} & 411.846 & 4.746 & $4.75 \mathrm{E}-03$ & 5 \\
\hline & 417.939 & Large spectral interference & Rejected & $<0.05$ \\
\hline & 422.535 & 0.465 & $4.65 \mathrm{E}-04$ & 50 \\
\hline & 414.311 & 4.632 & $4.63 \mathrm{E}-03$ & 5 \\
\hline \multirow[t]{4}{*}{$\mathrm{Lu}$} & 261.542 & BDL & - & 1000 \\
\hline & 291.139 & 1.924 & $1.92 \mathrm{E}-03$ & 10 \\
\hline & 307.76 & 0.434 & $4.34 \mathrm{E}-04$ & 500 \\
\hline & 219.554 & 0.169 & $1.69 \mathrm{E}-04$ & 500 \\
\hline \multirow[t]{4}{*}{$\mathrm{Yb}$} & 328.937 & BDL & - & 1000 \\
\hline & 369.419 & 0.353 & $3.53 \mathrm{E}-04$ & 100 \\
\hline & 222.446 & 0.402 & $4.02 \mathrm{E}-04$ & 100 \\
\hline & 289.138 & 0.778 & $7.78 \mathrm{E}-04$ & 50 \\
\hline \multirow[t]{3}{*}{$\mathrm{La}$} & 408.672 & Large spectral interference & Rejected & $<0.05$ \\
\hline & 333.749 & 4.055 & $4.06 \mathrm{E}-03$ & 10 \\
\hline & 379.478 & 0.904 & $9.04 \mathrm{E}-04$ & 50 \\
\hline
\end{tabular}

BDL: Below detection limit; Correction factor $=(\mu \mathrm{g} / \mathrm{mL}$ per $\mu \mathrm{g} / \mathrm{mL}$ of $\mathrm{Th})$. 
TABLE VI

Analytical Performances of Different Analytical Lines of Rare Earth Elements

\begin{tabular}{|c|c|c|c|}
\hline Elements & $\begin{array}{l}\text { Analytical Line } \\
(\mathrm{nm})\end{array}$ & $\begin{array}{c}\text { D.L. } \\
(\mu \mathrm{g} / \mathrm{mL})\end{array}$ & $\begin{array}{c}\text { Sensitivity } \\
\text { (counts } / \mu \mathrm{g} / \mathrm{mL})\end{array}$ \\
\hline \multirow[t]{5}{*}{$\mathrm{Ce}$} & 393.373 & 0.17 & 97131 \\
\hline & 413.38 & 0.006 & 11397 \\
\hline & 413.765 & 0.009 & 13022 \\
\hline & 418.66 & 0.01 & 12577 \\
\hline & 448.691 & 0.06 & 10610 \\
\hline \multirow[t]{4}{*}{$\mathrm{Er}$} & 323.058 & 0.001 & 2656 \\
\hline & 326.478 & 0.0003 & 8980 \\
\hline & 337.271 & 0.0007 & 17204 \\
\hline & 349.91 & 0.0016 & 8987 \\
\hline \multirow[t]{3}{*}{$\mathrm{La}$} & 333.749 & 0.0028 & 9852 \\
\hline & 379.478 & 0.002 & 12197 \\
\hline & 408.672 & 0.0003 & 9633 \\
\hline \multirow[t]{4}{*}{$\mathrm{Lu}$} & 219.554 & 0.005 & 4034 \\
\hline & 261.542 & 0.0003 & 3592 \\
\hline & 291.139 & 0.0009 & 4234 \\
\hline & 307.76 & 0.0005 & 7373 \\
\hline \multirow[t]{4}{*}{$\mathrm{Nd}$} & 401.225 & 0.002 & 8206 \\
\hline & 406.109 & 0.0036 & 8543 \\
\hline & 417.731 & 0.018 & 14769 \\
\hline & 430.358 & 0.009 & 10510 \\
\hline \multirow[t]{4}{*}{$\operatorname{Pr}$} & 411.846 & 0.009 & 10912 \\
\hline & 414.311 & 0.0055 & 11662 \\
\hline & 417.939 & 0.009 & 12682 \\
\hline & 422.535 & 0.003 & 12779 \\
\hline \multirow[t]{9}{*}{ Y } & 224.306 & 0.033 & 4955 \\
\hline & 320.332 & 0.0014 & 10494 \\
\hline & 324.228 & 0.0003 & 6628 \\
\hline & 349.609 & 0.002 & 9076 \\
\hline & 360.073 & 0.0001 & 6949 \\
\hline & 362.871 & 0.002 & 6337 \\
\hline & 371.03 & 0.00008 & 9964 \\
\hline & 377.433 & 0.0001 & 11297 \\
\hline & 442.259 & 0.027 & 11457 \\
\hline \multirow[t]{4}{*}{$\mathrm{Yb}$} & 222.446 & 0.0045 & 3743 \\
\hline & 298.138 & 0.0006 & 3696 \\
\hline & 328.937 & 0.00005 & 9328 \\
\hline & 369.419 & 0.0001 & 8914 \\
\hline
\end{tabular}

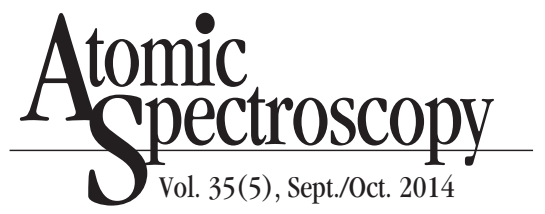

Neodymium, Erbium, Cerium and Yttrium

Neodymium (Nd)

Spectral interference of Th on the $401.225 \mathrm{~nm}, 430.358 \mathrm{~nm}$, $406.109 \mathrm{~nm}$ and $417.731 \mathrm{~nm} \mathrm{Nd}$ lines revealed that though the tolerance limit of Th is $100 \mu \mathrm{g} / \mathrm{mL}$ for the first three analytical lines, the $406.109 \mathrm{~nm}$ line showed the least contribution from Th (i.e., least spectral interference). The analytical performance of the $401.225 \mathrm{~nm}$ line is the best among the specified lines, followed by $406.109 \mathrm{~nm}$.

Therefore, the $406.109 \mathrm{~nm}$ line for $\mathrm{Nd}$ can be chosen for trace determination of $\mathrm{Nd}$ in a Th matrix, while the $\mathrm{Nd} 417.731 \mathrm{~nm}$ line is most interfered having the poorest analytical performance.

\section{Erbium (Er) and Yttrium (Y)}

Four analytical lines for Er $(337.271 \mathrm{~nm}, 349.910 \mathrm{~nm}, 326.478$ $\mathrm{nm}$ and $323.058 \mathrm{~nm}$ ) and nine lines for $Y(371.030 \mathrm{~nm}, 324.228 \mathrm{~nm}$, $360.073 \mathrm{~nm}, 224.306 \mathrm{~nm}, 377.433$ $\mathrm{nm}, 320.332 \mathrm{~nm}, 349.609 \mathrm{~nm}$, $362.871 \mathrm{~nm}$, and $442.259 \mathrm{~nm}$ ) were chosen for the present study. For both analytes, the best performing analytical line of Er at $326.478 \mathrm{~nm}$ and $\mathrm{Y}$ at $371.030 \mathrm{~nm}$ was found to show least spectral interference. Both the above-mentioned lines of Er and Y showed $100 \mu \mathrm{g} / \mathrm{mL}$ of Th tolerance, while the detection limits were found to be $0.0003 \mu \mathrm{g} / \mathrm{mL}$ and $0.00008 \mu \mathrm{g} / \mathrm{mL}$, respectively.

\section{Cerium (Ce)}

The $393.373 \mathrm{~nm}$ and 448.691 $\mathrm{nm}$ analytical lines of Ce showed high spectral interference from Th. Due to the numerous spectral interferences, these lines could not be used for trace determination of $\mathrm{Ce}$ in a Th matrix and hence, were rejected. The tolerance level of Th is $50 \mu \mathrm{g} / \mathrm{mL}$ for the $418.66 \mathrm{~nm} \mathrm{Ce}$ line and $5 \mu \mathrm{g} / \mathrm{mL}$ for the 413.765 $\mathrm{nm}$ and $413.380 \mathrm{~nm}$ Ce lines; the latter two lines have slightly better detection limits $(0.009 \mu \mathrm{g} / \mathrm{mL})$ than the former line $(0.01 \mu \mathrm{g} / \mathrm{mL})$. We 
believe that the $418.660 \mathrm{~nm}$ Ce line might be the best choice of analytical line in the presence of Th.

\section{Praseodymium, Lutetium, Lan- thanum, and Ytterbium}

\section{Praseodymium (Pr)}

Out of the four chosen analytical lines of $\operatorname{Pr}(411.846 \mathrm{~nm}, 417.939$ $\mathrm{nm}, 422.535 \mathrm{~nm}$ and $414.311 \mathrm{~nm})$, the $417.939 \mathrm{~nm}$ line showed drastic spectral contribution from the Th spectra and can be rejected, while the best performing analytical line, i.e., $\operatorname{Pr}$ at $422.535 \mathrm{~nm}$, showed the lowest Th interference with a tolerance limit of $50 \mu \mathrm{g} / \mathrm{mL}$ of Th.

\section{Lutetium (Lu) and Ytterbium (Yb)}

The $261.542 \mathrm{~nm}$ analytical line was found to be the best analytical line of Lu among the group of analytical lines studied in the present case $(261.542 \mathrm{~nm}, 291.139 \mathrm{~nm}$, $307.760 \mathrm{~nm}$, and $219.554 \mathrm{~nm}$ ) and is free of spectral interference from thorium. Similarly for $\mathrm{Yb}$, the best performing analytical line of $328.937 \mathrm{~nm}$ was found to be free of spectral interference from Th among its four analytical lines of 328.937 nm, 369.419 nm, 222.446 $\mathrm{nm}$, and $289.138 \mathrm{~nm}$ under present investigation.

\section{Lanthanum (La)}

For La, unfortunately the best analytical line of $408.672 \mathrm{~nm}$ is highly interfered by Th; hence, this line is not recommended for the determination of La in a Th matrix. Between the other two analytical lines of $\mathrm{La}$ (i.e., $333.749 \mathrm{~nm}$ and $379.478 \mathrm{~nm}$ ) which were investigated, the $379.478 \mathrm{~nm}$ line showed a higher tolerance of Th (up to 50 $\mu \mathrm{g} / \mathrm{mL}$ ), while both of the lines have similar detection limits $(\sim 0.002 \mu \mathrm{g} / \mathrm{mL})$. Therefore, the $379.478 \mathrm{~nm}$ La line should be the choice for trace determination of La in a Th matrix.

\section{Determination of $\mathrm{Cd}, \mathrm{Eu}, \mathrm{Lu}$, and $Y \mathbf{b}$ in Thorium Matrix Without Separation}

Due to the emission-rich spectra of U, Pu, Am, Zr, etc., the methodology proposed for the determination of trace elements in nuclear materials involves the quantitative separation of the major matrix without loss of impurities even at the trace level, followed by feeding of the raffinate to the plasma for trace analysis. The above spectral interference study revealed that there was no spectral interference of Th on the Cd $214.438 \mathrm{~nm}$, Eu $381.967 \mathrm{~nm}$, Lu $261.542 \mathrm{~nm}$, and Yb $328.937 \mathrm{~nm}$ lines. This suggests the possibility of direct determination of $\mathrm{Cd}, \mathrm{Eu}, \mathrm{Lu}$, and $\mathrm{Yb}$ in a thorium matrix without separation. Three synthetic samples were prepared as follows:

1. $\mathrm{S}-1=0.1 \mu \mathrm{g} / \mathrm{mL}$ of $\mathrm{Eu}, \mathrm{Yb}$, $\mathrm{Cd}$, and $\mathrm{Lu}$ in $1000 \mu \mathrm{g} / \mathrm{mL}$ of Th

2. $\mathrm{S}-2=1 \mu \mathrm{g} / \mathrm{mL}$ of $\mathrm{Eu}, \mathrm{Yb}$, $\mathrm{Cd}$, and $\mathrm{Lu}$ in $1000 \mu \mathrm{g} / \mathrm{mL}$ of $\mathrm{Th}$

3. $\mathrm{S}-3=10 \mu \mathrm{g} / \mathrm{mL}$ of $\mathrm{Eu}, \mathrm{Yb}$, $\mathrm{Cd}$, and $\mathrm{Lu}$ in $1000 \mu \mathrm{g} / \mathrm{mL}$ of $\mathrm{Th}$
These synthetic samples were analyzed directly by ICP-AES without chemical separation. It was observed that Eu, Cd, Lu, and $\mathrm{Yb}$ can be determined up to $0.1 \mu \mathrm{g} / \mathrm{mL}$ with a RSD of less than $2 \%$. The analytical results were compared with the routinely employed method, i.e., quantitative extraction of thorium by CYANEX-923, followed by analysis of the raffinate for trace analytes (33). This proposed method for the direct determination of the analytes compared well with routinely employed methods (Table VII). Since chemical separation is not required for the newly adopted method, the chances of contamination or loss of analytes are minimized. The overall recovery and precision were also found to be better using the present method.

TABLE VII

Direct determination of $\mathrm{Cd}, \mathrm{Eu}, \mathrm{Lu}$, and $\mathrm{Yb}$ in Thorium Matrix

\begin{tabular}{|c|c|c|c|c|c|c|c|}
\hline $\begin{array}{l}\text { Synthetic } \\
\text { Sample }\end{array}$ & $\begin{array}{l}\text { Ele- } \\
\text { ment }\end{array}$ & $\begin{array}{l}\text { Analytical } \\
\text { Line (nm) }\end{array}$ & $\begin{array}{c}\text { Actual } \\
\text { Conc. } \\
(\mu \mathrm{g} / \mathrm{mL})\end{array}$ & $\begin{array}{c}\text { Estimated } \\
\text { Conc. } \\
\text { Present } \\
\text { Method }\end{array}$ & $\begin{array}{c}(\%) \\
\text { Recovery }\end{array}$ & $\begin{array}{l}\text { Estimated } \\
\text { Conc. } \\
\text { After } \\
\text { Chemical } \\
\text { Separation }\end{array}$ & $\begin{array}{l}d \quad(\%) \\
\text { Recovery } \\
1 \\
n\end{array}$ \\
\hline \multirow[t]{4}{*}{ S-1 } & $\mathrm{Eu}$ & 381.967 & 0.1 & 0.096 & 96 & 0.089 & 89 \\
\hline & $\mathrm{Cd}$ & 214.438 & 0.1 & 0.098 & 98 & 0.091 & 91 \\
\hline & $\mathrm{Yb}$ & 328.937 & 0.1 & 0.11 & 110 & 0.09 & 90 \\
\hline & $\mathrm{Lu}$ & 261.542 & 0.1 & 0.1 & 100 & 0.093 & 93 \\
\hline \multirow[t]{4}{*}{ S-2 } & $\mathrm{Eu}$ & 381.967 & 1 & 1.1 & 110 & 0.9 & 90 \\
\hline & $\mathrm{Cd}$ & 214.438 & 1 & 1 & 100 & 0.87 & 87 \\
\hline & $\mathrm{Yb}$ & 328.937 & 1 & 0.99 & 99 & 0.92 & 92 \\
\hline & $\mathrm{Lu}$ & 261.542 & 1 & 1 & 100 & 0.93 & 93 \\
\hline \multirow[t]{4}{*}{$S-3$} & $\mathrm{Eu}$ & 381.967 & 10 & 9.9 & 99 & 9.1 & 91 \\
\hline & $\mathrm{Cd}$ & 214.438 & 10 & 10 & 100 & 8.5 & 85 \\
\hline & $\mathrm{Yb}$ & 328.937 & 10 & 11 & 110 & 9.2 & 92 \\
\hline & $\mathrm{Lu}$ & 261.542 & 10 & 9.7 & 97 & 9.1 & 91 \\
\hline
\end{tabular}




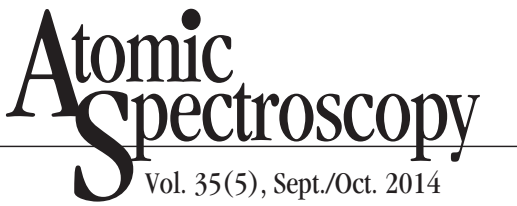

Determination of Other

Analytes in a Th Matrix Without

Separation After Incorporating Appropriate Correction Factors

In a similar fashion as above, synthetic samples were prepared and fed to the plasma for the determination of the analytes. The Ag 338.289 nm, B $182.641 \mathrm{~nm}$, Gd 335.047 nm, Dy 394.468 nm, Sm 359.260 nm, Nd 406.109 nm, Er 326.478 nm, Y 371.030 nm, $\operatorname{Pr} 422.535 \mathrm{~nm}$, Ce $418.660 \mathrm{~nm}$, and $\mathrm{La} 379.478 \mathrm{~nm}$ lines were used for this purpose. It was observed that all of these analytes can be determined even at $1 \mu \mathrm{g} / \mathrm{mL}$ in the presence of a Th matrix (1000 $\mu \mathrm{g} / \mathrm{mL}$ ) without chemical separation, and after applying appropriate correction factors as calculated above. Table VIII summarizes the analytical results of the synthetic samples.

\section{CONCLUSION}

A systematic study on the spectral interference of thorium on rare earths and critical elements was carried out. Several analytical lines of the elements were identified for this purpose. The study included identification of the relatively interference-free analytical line, evaluation of the correction factors wherever necessary, and the tolerance level of thorium on the analytical lines. The analytical performance of these analytical lines were studied in detail. The analytical lines that are somewhat free from Th spectral interference can be chosen for the determination of analytes without error. Hence, the analytical methodology becomes simpler and much more reliable. Since the metallurigical properties of the Th-based fuel depends on the presence of impurities even at trace levels, using interference-free lines will give the correct estimates of these analytes which in turn decides whether the quality of Th is of nuclear grade or not. The
TABLE VIII

Direct Determination of Other Analytes in Thorium Matrix After Incorporating Appropriate Correction Factors

\begin{tabular}{|c|c|c|c|c|c|}
\hline \multirow[b]{2}{*}{ Element } & \multirow[b]{2}{*}{$\begin{array}{c}\text { Analytical } \\
\text { Line } \\
(\mathrm{nm})\end{array}$} & \multicolumn{2}{|c|}{ S-4 } & \multicolumn{2}{|c|}{ S-5 } \\
\hline & & $\begin{array}{c}\text { Actual } \\
\text { Conc. } \\
(\mu \mathrm{g} / \mathrm{mL})\end{array}$ & $\begin{array}{c}\text { Amount } \\
\text { Estimated } \\
(\mu \mathrm{g} / \mathrm{mL})\end{array}$ & $\begin{array}{c}\text { Actual } \\
\text { Conc. } \\
(\mu \mathrm{g} / \mathrm{mL})\end{array}$ & $\begin{array}{l}\text { Amount } \\
\text { Estimated } \\
(\mu \mathrm{g} / \mathrm{mL})\end{array}$ \\
\hline $\mathrm{Ag}$ & 338.289 & 1 & 1.1 & 10 & 9.6 \\
\hline B & 182.641 & 1 & 0.97 & 10 & 10.5 \\
\hline Gd & 335.047 & 1 & 1 & 10 & 10.3 \\
\hline Dy & 394.468 & 1 & 1 & 10 & 10 \\
\hline $\mathrm{Sm}$ & 359.26 & 1 & 1.2 & 10 & 9.9 \\
\hline $\mathrm{Nd}$ & 406.109 & 1 & 0.99 & 10 & 9.8 \\
\hline $\mathrm{Er}$ & 326.478 & 1 & 0.99 & 10 & 10 \\
\hline $\mathrm{Y}$ & 371.03 & 1 & 0.97 & 10 & 10.1 \\
\hline $\operatorname{Pr}$ & 422.535 & 1 & 0.98 & 10 & 10.1 \\
\hline $\mathrm{Ce}$ & 418.66 & 1 & 1.1 & 10 & 9.8 \\
\hline $\mathrm{La}$ & 379.478 & 1 & 1 & 10 & 9.9 \\
\hline
\end{tabular}

study revealed that $\mathrm{Ag}$ at 338.289 $\mathrm{nm}, \mathrm{B}$ at $182.641 \mathrm{~nm}, \mathrm{Gd}$ at $335.047 \mathrm{~nm}$, Dy at $394.468 \mathrm{~nm}, \mathrm{Sm}$ at $359.260 \mathrm{~nm}, \mathrm{Nd}$ at $406.109 \mathrm{~nm}$, Er at $326.478 \mathrm{~nm}, \mathrm{Y}$ at $371.030 \mathrm{~nm}$, Pr at $422.535 \mathrm{~nm}$, Ce at 418.660 $\mathrm{nm}$, and $\mathrm{La}$ at $379.478 \mathrm{~nm}$ are suitable analytical lines for the determination of these analytes in the presence of a Th matrix. It was also noted that the analytical lines of Cd at $214.438 \mathrm{~nm}$, Eu at $381.967 \mathrm{~nm}$, $\mathrm{Lu}$ at $261.542 \mathrm{~nm}$, and $\mathrm{Yb}$ at $328.937 \mathrm{~nm}$ were free from any spectral interference of thorium even at $1000 \mu \mathrm{g} / \mathrm{mL}$ of Th. Since the spectral interference largely depends on the amount of thorium concentration, an ICP-AES-based method was developed for the simultaneous determination $\mathrm{Th}$. Of the four Th analytical lines identified, the $401.913 \mathrm{~nm}$ Th line showed the best analytical performance.

Received April 3, 2014. 


\section{REFERENCES}

1. R.K. Malhotra and K. Satyanarayana, Talanta 50 (3), 601 (1999).

2. E.A. Huff, Spectrochim. Acta Part B: Atomic Spectroscopy, 42 (1-2), 275 (1987).

3. E.A. Huff and D.L. Bowers, Appl. Spectrosc. 43(2), 223 (1989).

4. A. Sengupta, B. Rajeswari, R.M. Kadam, and R. Acharya, At. Spectrosc. 32(5), 200 (2011).

5. A. Sengupta, V.C. Adya, Mithelesh Kumar, S.K. Thulasidas, S.V. Godbole, and V.K. Manchanda, At. Spectrosc. 32(2), 49 (2011).

6. Arijit Sengupta, B. Rajeswari, R.M.Kadam, and S.V.Godbole, At. Spectrosc. 33(2), 48 (2012).

7. K. Satyanarayana and S. Durrani, J Radioanal. Nucl. Chem. 285 (3), 659 (2010).

8. B. Rajeswari, B.A. Dhawale, T.R. Bangia, J.N. Mathur and A.G. Page, J Radioanal. Nucl. Chem. 254 (3), 479 (2002).

9. A. Sengupta, M. J. Kulkarni and S. V. Godbole, J. Radioanal. Nucl. Chem. 289(3), 961 (2011).

10. A.A. Argekar, M.J. Kulkarni, J.N. Mathur and A.G. Page, Talanta 56 (4), 591 (2002).

11. C. Mahan, S. Bonchin, D. Figg, D. Gcrth and C. Collier, J. Anal. At. Spectrom. 15 (8), 929 (2000).

12. S. Marin, S. Cornejo, C. Jara and N. Durani, Fresenius' J. of Anal. Chem. 355 (5-6), 680 (1996).

13. T.G. Bangia, B.A. Dhawale, V.C. Adya and M.D. Sastry, Fresenius J. Anal. Chem. 332, 802 (1988).

14. N.K. Porwal, A.A. Argekar, P.J. Purohit, A.G. Page, and M.D. Sastry, Fresenius J. Anal. Chem. 338, 255 (1990).

15. A. G. Page, K. H. Madraswala, S. V. Godbole, Madhuri J. Kulkarni, Vanita S. Mallapurkar, and B. D. Joshi, Fresenius Z. Anal. Chem. 315, 38 (1983) .

16. A.G. Page, S.V.Godbole, S. Deshkar, Y. Babu and B.D. Joshi, J. Anal. Chem. 287, 304 (1977).
17. A.G.I. Dalvi, C.S. Deodhar, T.K. Seshagiri, M.S. Khalap and B.D. Joshi, Talanta 25, 665 (1978).

18. T.G. Bangia, B.A. Dhawale, V.C. Adya and M.D. Sastry, Fresenius J Anal. Chem. 332, 802 (1988).

19. V.C. Adya, Arijit Sengupta and S.V. Godbole, At. Spectrosc. 35(1), 25 (2014).

20. Arijit Sengupta, V.C. Adya, T.K. Seshagiri, and S.V. Godbole, Atomic Spectroscopy, 34(2), 53 (2013)

21. Aijit Sengupta, V.C. Adya and S.V. Godbole, J. Radioanal. Nucl. Chem. DOI 10.1007/s10967-0132520-0 (2013).

22. Arijit Sengupta and V.C.Adya, At. Spectrosc. 34(6), 207 (2013).

23. "IAEA-TECDOC-1450, Thorium Fuel Cycle-Potential Benefits and Challenges", International Atomic Energy Agency, (May 2005) 200903-23.

24. Ganesan Venkataraman, Bhabha and his magnificent obsessions, page 157, Universities Press, location??? (1994).

25. "IAEA-TECDOC-1349 Potential of thorium-based fuel cycles to constrain plutonium and to reduce the long-lived waste toxicity", International Atomic Energy Agency, Retrieved 2009-03-24 (2002).

26. Evans Brett, "Scientist urges switch to thorium", ABC News, Archived from the original on 2010-03-28, Retrieved 2011-09-17 (2006).

27. Martin Richard, "Uranium Is So Last Century - Enter Thorium, the New Green Nuke", Wired, Retrieved 2010-06-19 (2009).

28. "The Use of Thorium as Nuclear Fuel" (PDF), American Nuclear Society, Retrieved 2009-03-24 (2006)

29. J.L.M. de Boer, W. van Leeuwen, U. Kohlmeyer and P.M. Breug, Fresenius J. Anal. Chem. 360, 213 (1998)

30. P. Bustamante, C. Garrigue, L. Breaua, F. Caurant, W. Dabind, J. Greaves and R. Dodemontb, Environmental Pollution 124(2), 263 (2003).
31. X.L. Mao, A.C. Ciocan, O.V. Borisov and R.E. Russo, Applied Surface Science 127-129, 262 (1998).

32. K.P. Ravena1, J.W. Reynolds and R.H. Loeppert, Communications in Soil Science and Plant Analysis 28(3-5), 237 (1997).

33. M.J. Kulkarni, A.A. Argekar, J.N. Mathur and A.G. Page, Anal. Chim. Acta 370 (2-3), 163 (1998). 